\title{
Novel Method for the Preparation of Mesoporous BaSO 4 Material with Thermal Stability by Spray Pyrolysis
}

\author{
Bhari Mallanna Nagaraja, Haznan Abimanyu, ${ }^{a}$ Kwang Deog Jung, and Kye Sang Yoo ${ }^{\dagger *}$ \\ Clean Energv Research Center, Korea Institute of Science and Technologv, P.O. Box 131, Cheongryang, Seoul 130-650, Korea \\ Department of Chemical Engineering, Seoul National Lniversity of Technologv, Seoul 139-743, Korea \\ ${ }^{*}$ E-mail: hoo âsmutackr \\ Received Jahucirv 24, 2008
}

\begin{abstract}
Spray pyrolysis has been found as an excellent method for the preparation of mesoporous barium sulfate at higher temperature. Ethylene glycol. a reducing agent. and solvents had good inhibition effect for the preparation of $\mathrm{BaSO}_{4}$ nano particles. The $\mathrm{BaSO}_{4}$ solution was sprayed at $500 \& 800^{\circ} \mathrm{C}$ using different solvents such as methanol. ethanol. propanol and $n$-butyl alcohol. $\mathrm{N}_{2}$ adsorption-desorption isotherm revealed that $\mathrm{BaSO}_{4}$ is micropore free. possessing narrow mesopores size distribution and high BET surface areas of 72.52 $\mathrm{m}^{2} \mathrm{~g}^{-1}$ at $800{ }^{\circ} \mathrm{C}$ using propanol as an additive. Scanning electron microscopy (SEM) indicates that the morphology of $\mathrm{BaSO}_{+}$nano material shows uniform shell like particles. Transmission electron microscopy (TEM) proved that the resulting $\mathrm{BaSO}_{4}$ nano particles were uniform in size and the average particle size was 4-8 $\mathrm{nm}$. The surface functionality and ethylene glycol peaks were assessed by Fourier transform infrared resonance (FTIR) spectroscopy. Low intensity ethylene glycol specific absorption peak was observed in propanol which proved that propanol had good inhibition effect on the stnuctural morphology of nano particles.
\end{abstract}

Key Words : Mesoporous. Barium hydroxide, Spray pyrolysis, Ethylene glycol

\section{Introduction}

Barium sulfate $\left(\mathrm{BaSO}_{4}\right)$ is suitable for many diverse applications due to its whiteness. inertness. opaqueness to Xrays and high specific gravity. It is extensively utilized in industrial applications such as paper coatings. fillers in plastics. synthetic resins and pigment used in paint and artificial fibres. $\mathrm{BaSO}_{4}$ assesses the effect of precursors mixing. precipitation models agitator speed. feed position on particle size distribution. crystal growth and morphology: ${ }^{-4}$ Barium sulfate prepared by using copolymers via atom transfer radical polymerisation. polymerized surfactants. polymer-controlled mineralization reactions and double hydrophilic copolymer mixtures. ${ }^{5-\delta}$ Bala et $a$. reported the preparation of $\mathrm{BaSO}_{4}$ nano particles with selfdispersing properties without additional treatments with insitu preparation and surface modification of $\mathrm{BaSO}_{4}$ nano particles ${ }^{9.10} \mathrm{Li}$ et al. reported the performance of barium sulfate nanotube arrays in supporting sulfates for lowtemperature methane activation and detailed information on the preparation of three types of mesostnuctured barium sulfate (lamellar, agglomerate and single nanotube) under various preparation conditions. ${ }^{11.12}$ We reported the preparation of mesostructured barium sulfate with high surface area by dispersion method and its characterization. ${ }^{13}$

Spray pyrrolysis is a useful method for producing multi component. high-purity powders that consist of nonagglomerated sub micrometer-sized particles. ${ }^{14}$ Spray pỵrolysis is a useful tool for the large or small scale production

${ }^{a}$ Current address: Research Center for Chemistry Indonesian Institute of Sciences (LIPI), Kawasan PUSPIPTEK Serpong. Tangerang. Indonesia with controlled particle size. The properties of the final product can be controlled through the choice of precursor and solution concentration or by changing the conditions of aerosol decomposition. The micrometre-sized droplets of a precursor solution are dried and pyrolysed in a furnance forming particles. ${ }^{15.16}$ Microfoamy particles of copper oxide and nitride by spray pyrolysis of copper-ammine complex solution and also spray pyrolyis has been applied to the production of particles with tailored microstnucture..$^{17.18}$ Generally. in spray pyrolysis process. the reaction temperature and the composition of the carrier gas are the basic operating variables. In addition, the solution properties such as the precursor compositions. concentration or the addition of a co-solvent are crucial to achieve the desired composition and morphology of the final product. ${ }^{19}$ Spray pyrolysis is advantageous almost all steps of powder processing from solution take place continuously in each droplet.

In this paper we reported that the high surface area mesoporous $\mathrm{BaSO}_{4}$ small sized nano particles was prepared by spray pyrolysis at high temperature. Ethylene glycol is a good reducing agent and solvent with good inhibition effect on the particle size. The excellence of this work was the existence of mesoporosity with stability at the higher temperature and aggregation of $\mathrm{BaSO}_{4}$ nano material with ethylene glycol uniformly:

\section{Experimental Section}

Materials and methods. Preparation of $\mathrm{BaSO}_{4}$ solution is as follows: Mesoporous $\mathrm{BaSO}_{4}$ nano material were prepared by taking 5 wt. $\%$ of $\mathrm{Ba}(\mathrm{OH})_{2}-8 \mathrm{H}_{2} \mathrm{O}$ (Kanto Chemical $\mathrm{Co}$. Inc.. Japan) dissolved in $20 \mathrm{~mL}$ of ethylene glycol (EG) (J.T. 
Baker. USA) at $80^{\circ} \mathrm{C}$ with vigorous stirring. $3 \mathrm{~mL}$ of sulphuric acid $(97 \%$, Matsunoen Chemicals Ltd., Japan) was dissolved in $10 \mathrm{~mL}$ of EG in a separate beaker. After conplete mixing of $\mathrm{Ba}(\mathrm{OH})_{2} \cdot 8 \mathrm{H}_{2} \mathrm{O}$ with $\mathrm{EG}$ the diluted sulphuric acid was added into the mixture. The suspension was continuously stirred for $60 \mathrm{~min}$. and transferred into the flask. Before using spray pyrolysis. the different solvents such as methanol. ethanol. propanol and butanol was used and designated as $\mathrm{BaSO}_{4}-\mathrm{MeOH}$. $\mathrm{BaSO}_{4}-\mathrm{EtOH} . \mathrm{BaSO}_{4}-$ $\mathrm{PrOH}$ and $\mathrm{BaSO}_{4}-\mathrm{ButOH}$, respectively. Finally this solution was used for spray pyrolysis. In spray pyrolysis, water was also used as an additive but the solution hardly sprayed due to ligh viscosity. The spray nozzle $(0.8 \mathrm{~mm}$ i.d) was used to generate the aerosol droplets of the precursor solution with delivery rate of $100 \mathrm{~mL} \mathrm{~h}^{-1}$ and the flow rate of the carrier gas nitrogen was $400 \mathrm{~mL} \mathrm{~min}^{-1}$. In this method carrier gas hardly affect the preparation of $\mathrm{BaSO}_{+}$nano material. Finally the $\mathrm{BaSO}_{4}$ solution was used for spray pyrolysis at 500 and $800{ }^{\circ} \mathrm{C}$. Thus nano- $\mathrm{BaSO}_{+}$dried material was obtained and then dried at $110^{\circ} \mathrm{C}$ for $12 \mathrm{~h}$ in the air.

Characterization. The XRD patterns of mesoporous sprayed $\mathrm{BaSO}_{4}$ nano materials were recorded on $(\mathrm{M} / \mathrm{S}$. Shimadzu Instruments. Japan) diffractometer with Ni filtered $\mathrm{Cu} \mathrm{K} \alpha$ as a radiation source and at a $2 \theta$ scan speed of $2 \%$ min. The $\mathrm{N}_{2}$ adsorption-desorption measurements were performed at $77 \mathrm{~K}$ using automated gas sorption system (M/S. Micromeritics ASAP 2000) utilized with Brumner-EmmettTeller (BET) calculation for the surface area and BarrettJoyner-Halanda $(\mathrm{BJH})$ method for pore size distribution. The $\mathrm{BaSO}_{4}$ pre-treated at $200^{\circ} \mathrm{C}$ for $2 \mathrm{~h}$ before analyzing the sample. Scanning electron microscopy (SEM) was conducted by Nova 200 (Image resolution-1.0 $\mathrm{nm}$. acceleration voltage- $200-300 \mathrm{kV}$ and magnification $20-30 \mathrm{kV}$ ). The Transmission emission microscopy (TEM) analysis is the important characterization technique to calculate the $\mathrm{BaSO}_{4}$ particle size using CM30 microscope (Philips) with accelerating voltage $50-300 \mathrm{kV}$ of $\mathrm{LaB}_{6}$ filament to visually characterize mesoporous $\mathrm{BaSO}_{4}$ nano materials. The surface characteristics of the mesoporous $\mathrm{BaSO}_{4}$ powder materials were examined by' infrared spectra of wave number 4000 $400 \mathrm{~cm}^{-1}$ using Nicolet 380 (Thermo Electron Corporation).

Formation mechanism of BaSO 4 . The formation of mesoporous $\mathrm{BaSO}_{4}$ nano material probably starts by the following reactions. The significance of this reaction mechanism (Scheme 1) is that the reduction reaction proceeds via the solution rather than in solid state. Therefore the metal particles are fomed by nucleation and growth from the solution. This main feature is quite general for all investigated reactions and metals obtained by this poly'ol (ethylene glycol) process.

According to this mechanism the polyol acts first as a solvent (Eq. 1) for beginning inorganic compound due to the high dielectric constant of these organic media. In ethylene glycol the barium hydroxide salts were completely dissolved in the first step of reaction. In most cases the starting compound is slightly soluble.$^{30}$ In this case the solubility is high enough to allow the reaction mechanism. In first step

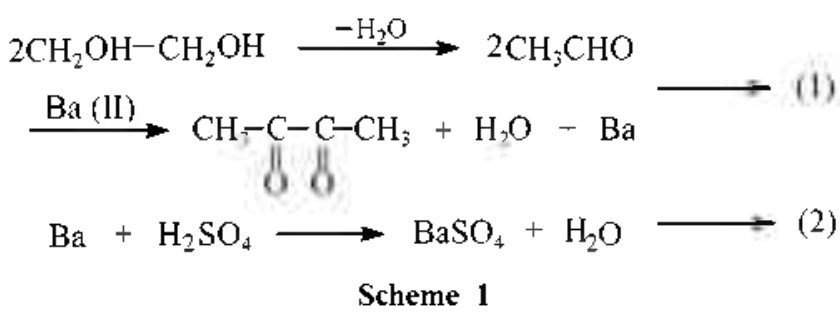

crystallized hydroxides were converted into intemediate phase. The hydroxide gets progressive dissolution, viscous solution of the intermediatery phase and evolution of water by evaporation.

The second step (Eq. 1) of reaction mechanism is redissolution of intermediate phase to metal (reduction in solution, evolution of the volatile products of reaction, spontaneous nucleation and growth of metal particles.). During this stage the intermediate solid phase takes place and the reduction of barium species occurs in the liquid phase. Finally the liquid Barium is interacted with sulphuric acid (Eq. 2) and converted into barium sulfate according to the reduction mechanism of metallic ions in ethylene glycol which was proposed by Fievet $e t$ al. ${ }^{2 i j}$

\section{Results and Discussion}

Figure I shows the XRD patterns of mesoporous $\mathrm{BaSO}_{4}$ nano materials prepared by spray pyrolysis with various solvents as an additive at $800{ }^{\circ} \mathrm{C}$. The XRD pattenns of the $\mathrm{BaSO}_{4}$ powders shows orthorhombic structure. The d-values of $\mathrm{BaSO}_{4}$ nano material was $4.34_{\mathrm{k}} .2 .12_{5}$ and $3.90_{4}$ (JCPDS No. 83-1718). 3.44, 3.10, and 2.127 (JCPDS No.83-2053) with hkl values of $(101)$. (311). (111) and (210). (211), (401) respectively. The XRD patten was indexed with reference to the unit cell of the barite structure $(a \sim 8.87, b \sim 5.45, c \sim$ $7.15 \mathrm{~A}$; space group Pnma) ${ }^{\text {}}{ }^{2}$ Only $\mathrm{BaSO}_{4}$ peaks were

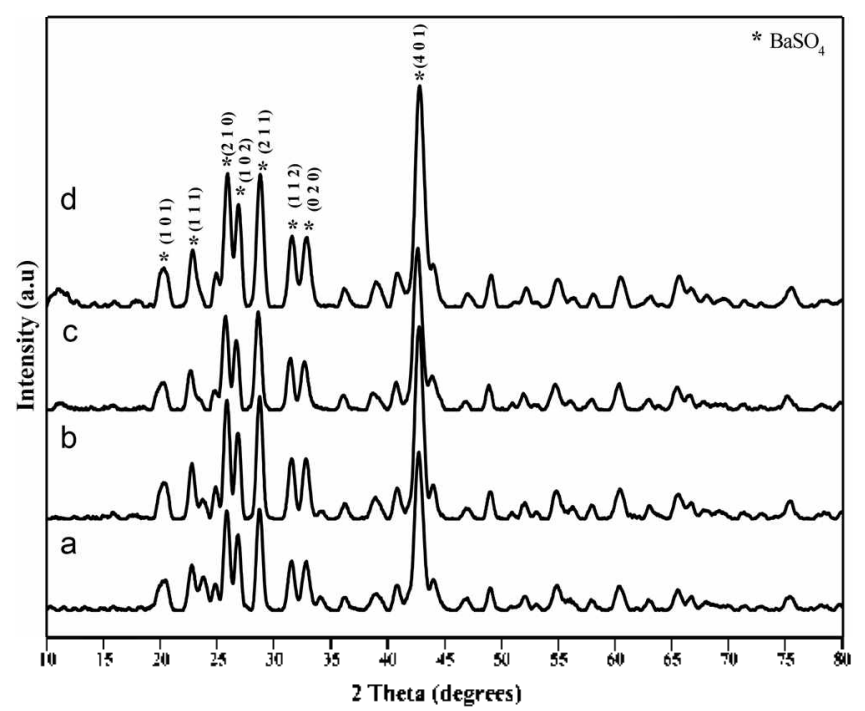

Figure 1. X-ray diffraction spectra of mesoporous $\mathrm{BaSO}_{\downarrow}$ nano material dried catalyst sprayed at $800^{\circ} \mathrm{C}$. a. $\mathrm{BaSO}_{4}-\mathrm{MeOH}$, b. $\mathrm{BaSO}_{4}-\mathrm{E}+\mathrm{OH}$, c. BaSO $4-\mathrm{HrOH}$. d. BaSO $4-\mathrm{ButOH}$. 

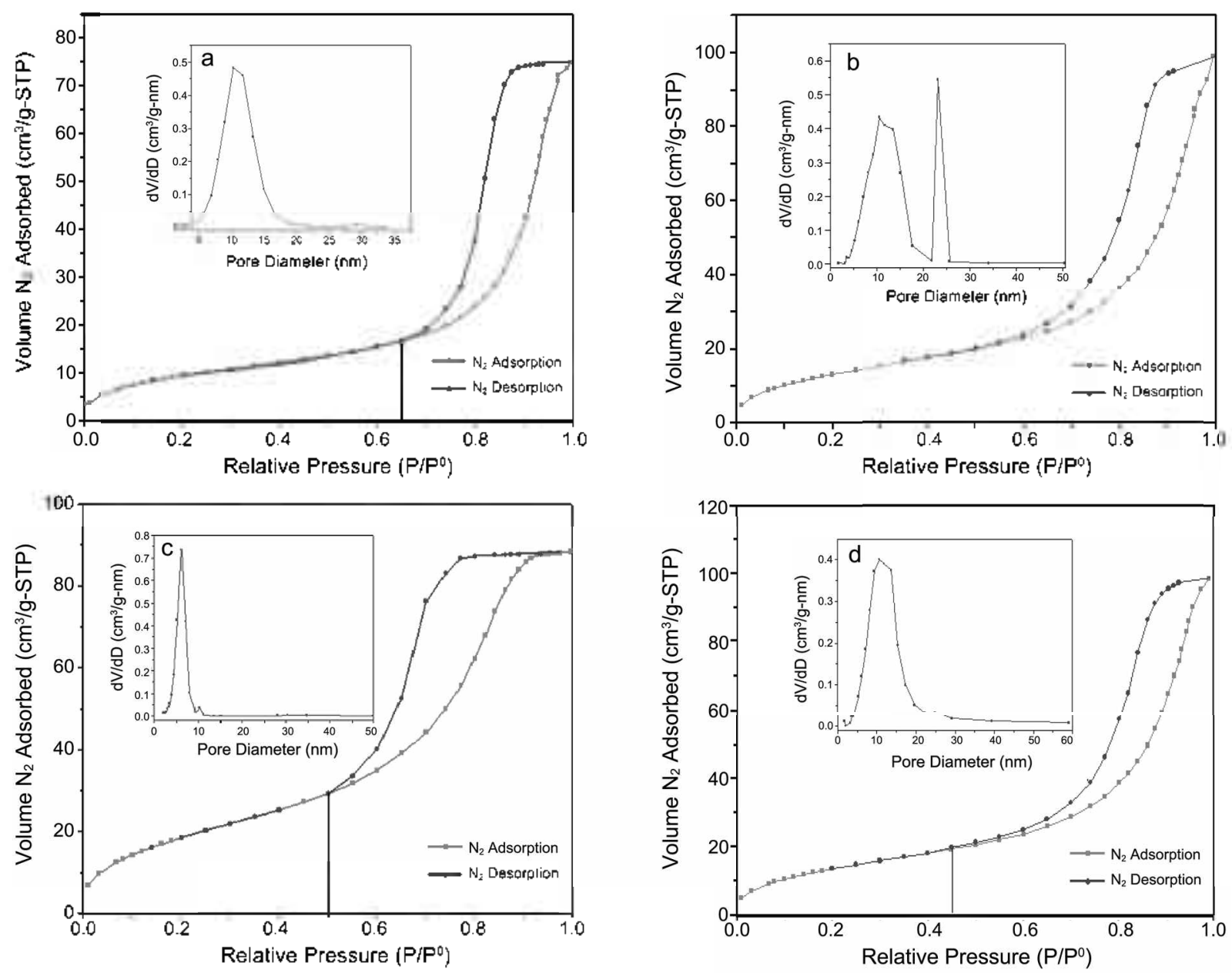

Figure 2. Nitrogen adsorption-desorption isothenn at $-196^{\circ} \mathrm{C}$ and pore size distribution of mesoporous BaSO nano material sprayed at $8(00$ ${ }^{\circ} \mathrm{C}$. a. BaSO $-\mathrm{MeOH}$, b. BaSO $-\mathrm{EtOH}$, c. $\mathrm{BaSO}-\mathrm{PrOH}$, d. BaSO $-\mathrm{ButOH}$.

observed in the XRD spectra which indicated that the powders had high purity in nature.

Figure 2 shows the $\mathrm{N}_{2}$ adsorption-desorption isotherm of $\mathrm{BaSO}_{4}$ nano material sprayed at $800^{\circ} \mathrm{C}$ using different solv-

Table 1. BET surface area and pore size distribution of mesoporons $\mathrm{BaSO}_{\downarrow}$ nano material using different solvents by spray pyrolysis with different temperature

\begin{tabular}{|c|c|c|c|c|}
\hline $\begin{array}{l}\text { Sl. Sample Name } \\
\text { No. }\end{array}$ & $\begin{array}{c}\text { BET Surface } \\
\text { area } \\
\mathrm{m}^{2} \mathrm{gm}^{-1}\end{array}$ & $\begin{array}{c}\mathrm{P} / \mathrm{P}^{0} \\
\mathrm{Hysteresis} \\
\text { Loop }\end{array}$ & $\begin{array}{l}\text { Pore } \\
\text { Volume } \\
\mathrm{cm}^{3} \mathrm{~g}^{-1}\end{array}$ & $\begin{array}{c}\text { Average Pore } \\
\text { Diameter } \\
\text { nun }\end{array}$ \\
\hline \multicolumn{5}{|c|}{$500^{\circ} \mathrm{C}$} \\
\hline 1. $\mathrm{BaSO}_{4}-\mathrm{MeOH}$ & 52.77 & 0.65 & 0.176 & 13.34 \\
\hline 2. $\mathrm{BaSO}_{4}-\mathrm{EtOH}$ & 50.53 & 0.50 & 0.152 & 12.04 \\
\hline 3. $\mathrm{BaSO}_{4}-\mathrm{PTOH}$ & 65.27 & 0.55 & 0.132 & 8.12 \\
\hline 4. $\mathrm{BaSO}_{4}-\mathrm{ButOH}$ & 40.58 & 0.45 & 0.105 & 10.34 \\
\hline \multicolumn{5}{|c|}{$800^{\circ} \mathrm{C}$} \\
\hline 1. $\mathrm{BaSO}_{4}-\mathrm{MeOH}$ & 36.17 & 0.50 & 0.114 & 12.63 \\
\hline 2. $\mathrm{BaSO}_{4}-\mathrm{EtOH}$ & 45.65 & 0.45 & 0.139 & 12.15 \\
\hline 3. $\mathrm{BaSO}_{4}-\mathrm{PrOH}$ & 72.52 & 0.50 & 0.136 & 7.54 \\
\hline 4. $\mathrm{BaSO}_{4}-\mathrm{ButOH}$ & 52.71 & 0.45 & 0.152 & 11.52 \\
\hline
\end{tabular}

ents. This isotherm pattern exhibited type IV-like behaviour which is a characteristic of mesoporous materials based on the IUPAC classification. ${ }^{2-}$ The $\mathrm{BaSO}_{4}$ nano materials sprayed at $500 \& 800 \mathrm{C}$ the BET surface area. pore size and pore volume were shown in Table 1 .

Figures $2 \mathrm{a} \& 2 \mathrm{~b}$ shows that the mesoporous $\mathrm{BaSO}_{4}$ nano material using methanol \& ethanol as an additive sprayed at $800^{\circ} \mathrm{C}$ with broad pore size distribution and the BET surface area were less at higher temperature. In Figures $2 \mathrm{c} \& 2 \mathrm{~d}$ using propanol and butanol as an additive the BET surface area was high at $800^{\circ} \mathrm{C}$. In propanol case the BET surface area at $500^{\circ} \mathrm{C}$ was $65.27 \mathrm{~m}^{2} \mathrm{~g}^{-1}$. At $800^{\circ} \mathrm{C}$ the surface area was $72.52 \mathrm{~m}^{2} \mathrm{~g}^{-1}$ because ethylene glycol was distributed uniformly on $\mathrm{Ba}^{-2}$ and $\mathrm{SO}_{4}{ }^{-2}$ particles. The formation of the mesoporous structure is related both to the nucleation and growth mechanism of $\mathrm{BaSO}_{4}$ particles. This proved that propanol is a good additive for the preparation of mesoporous $\mathrm{BaSO}_{4}$ nano material.

The results of the morphological studies can be interpreted in accordance with the classical molecular growth mechanisms. Figure 3 shows that $\mathrm{BaSO}_{4}$ solution was sprayed at $800{ }^{\circ} \mathrm{C}$ using different solvents. In Figure $3 \mathrm{c}$ shows the spherical shape nano particles were distributed uniformly 


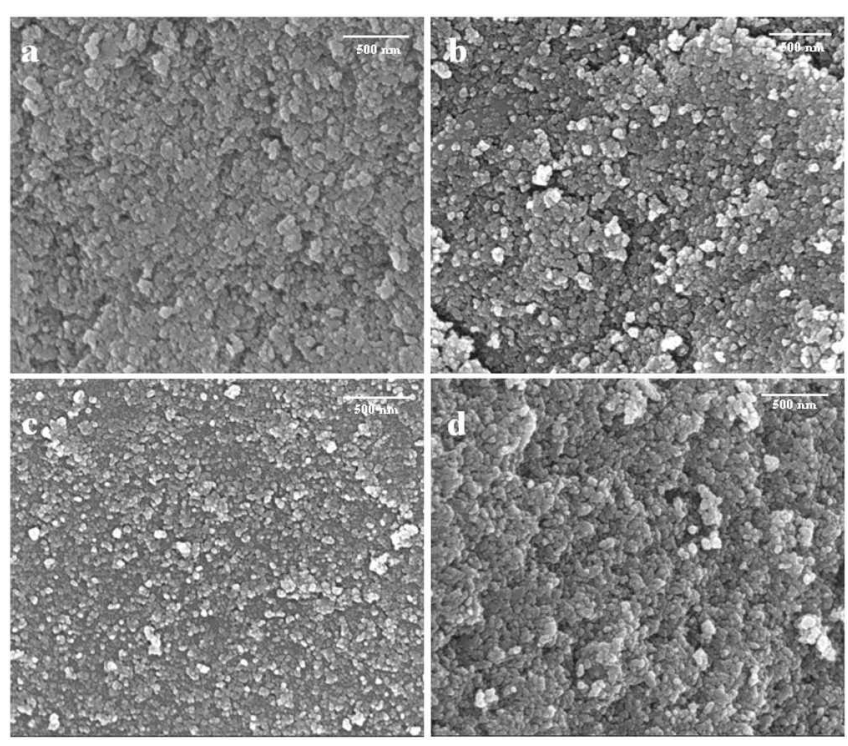

Figure 3. Scanning electron microscopy of mesoporous $\mathrm{BaSO}_{4}$ nano material using different solvents spraved at $800^{\circ} \mathrm{C}$ a. $\mathrm{BaSO}_{4}-$ $\mathrm{MeOH}$, b. BaSO - -EtOH, c. BaSO-PrOH, d. BaSO $-\mathrm{ButOH}$.

due to the ethylene glycols displacement systematically on $\mathrm{BaSO}_{4}$ nano materials compared to the other solvents. The particle size in all the compounds was $4-8 \mathrm{~lm}$ due to the addition of additives. The lower aggregration rate was attributed to the presence of an ethoxide group on the surface which was formed by replacing the coordinated water on the surface with ethylene glycol. As a result the powder had high dispersibility and small particle size. The etlyylene glycol therefore intproved the reaction conditions by favoring the formation of small particles and by restraining particle growth during the precipitation and drying processes.

The effects of additives may include three main aspects as follows. Additives can adsorb on the steps and kinks of the particle surface and decrease the numbers of free steps and kinks as well as the particle surface agglomeration. Furthermore the additives also affect the nucleation process. The result suggested that the inhibition effects mainly attributed to the adsorption of additives on the particles surface because according to the Traube rule reported by Jaycock $e t$ $a f . .^{\hat{3}}$ the $n$-butyl alcohol will reduce the solution tension most effectively due to its longer carbon chain. The adsorption of additives on the particles is a competitive process with the water molecules and determined by the molecular interaction between the $\mathrm{BaSO}_{4}$ surface and the additive, additives-water and $\mathrm{BaSO}_{4}-$ water. $\mathrm{Zia} e t \mathrm{cl} .^{ \pm 4}$ reviewed that the sequence of adsorption amount can be related qualitatively to that of the additives polarities i.e. methanol $\%$ ethanol $n$-butyl alcohol. In this case propanol has good inhibition effects on the particle size at higher temperature i.e. propanol $>$ n-butyl alcohol $>$ ethanol $>$ methanol. It clearly reveals that propanol has an excellent effect on the control of particle size and uniformly distributed over the surface of the substrate. Development of ethylene glycol at the sub-phase surface would also reduce the dielectric constant of the
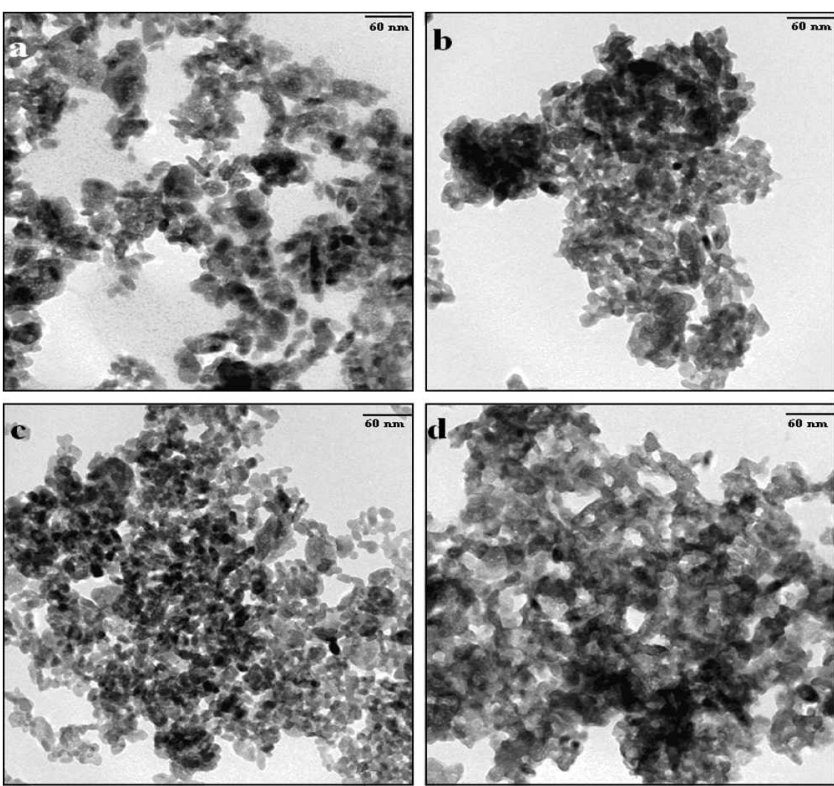

Figure 4. Transmission emission microscopy of mesoporous $\mathrm{BaSO}$ nano material using different solvents sprayed at $800^{\circ} \mathrm{C}$ a. $\mathrm{BaSO}-\mathrm{MeOH}$, b. BaSO $-\mathrm{EtOH}$, c. $\mathrm{BaSO}_{4}-\mathrm{PrOH}$, d. BaSOButOH.

interfacial region and thus lead to enhanced binding of barium ions at the interface. The use of the surface-active adsorbates at the ethylene glycol-solvents have the possibility of tailoring the physical and chemical properties and thereby modifying the morphology of the crystals nucleating and growing at the interface.

The Transmission emission microscopy (TEM) analysis was the important characterization technique to calculate the $\mathrm{BaSO}_{4}$ particle size to visually characterize mesoporous $\mathrm{BaSO}_{4}$ nano materials as showin in Figure 4. The TEM micrograph shows that the mesostructured $\mathrm{BaSO}_{4}$ nano particles are nearly shell like particles. The particle size between 4-8 num with an average size of $6 \mathrm{~nm}$ shows uniform mesopores among the particles and the diameter of the cavities is about $2-4 \mathrm{~nm}$. These regions appeared brighter because they had immersed small amount of electrons in the surroundings. The mesoporous $\mathrm{BaSO}_{4}$ nano material prepared by other solvents viz., methanol. ethanol and $n$-butyl alcohol shows that the particles get agglomerated and particles are not in unifom size at $800^{\circ} \mathrm{C}$. This revealed that the high dispersibility of the powder in etlylene glycol might be related to the mesopores particles and the high rate of adsorption of ethylene glycol onto their surfaces.

We reported that the high surface area mesoporous $\mathrm{BaSO}_{4}$ nano material was prepared by dispersion method. ${ }^{13} \mathrm{BaSO}_{4}$ nano materials prepared by different methods like dispersion using ethylene glycol. water as a solution and in spray pyrolysis using different solvents which acted as an additive calcined at $900{ }^{\circ} \mathrm{C}$. In spray pyrolysis method propanol showed high surface area, pore volume and size compared to the other methods as shown in Table 2. At $900^{\circ} \mathrm{C}$ the mesoporous structure remains in spray pyrolysis. This proved that spray pyrolysis method was suitable for the 
Table 2. BET surface area and pore size distribution of mesoporous $\mathrm{BaSO}_{4}$ dried and calcined at $900^{\circ} \mathrm{C}$ prepared using different methods (EG-Ethylene Glycol, $\mathrm{PrOH}$ - Propanol)

\begin{tabular}{|c|c|c|c|c|}
\hline $\begin{array}{l}\text { Sl. } \\
\text { No. }\end{array}$ & $\begin{array}{l}\text { Sample } \\
\text { Name }\end{array}$ & $\begin{array}{c}\text { BET Surface } \\
\text { area } \\
\mathrm{m}^{2} \mathrm{gm}^{-1}\end{array}$ & $\begin{array}{l}\text { Pore } \\
\text { volunne } \\
\operatorname{cmn}^{-2} \mathrm{~g}^{-1}\end{array}$ & $\begin{array}{c}\text { Average Pore } \\
\text { Diameter } \\
\text { nim }\end{array}$ \\
\hline \multicolumn{5}{|c|}{ Dried } \\
\hline 1. & $\mathrm{BaSO}_{4}-\mathrm{EG}$ & 91.56 & 0.1880 & 8.22 \\
\hline 2. & $\mathrm{BaSO}_{4}-\mathrm{H}_{2} \mathrm{O}$ & 14.50 & 0.0317 & 8.76 \\
\hline 3. & $\begin{array}{l}\mathrm{BaSO}_{4}-800 \mathrm{Sp} \\
(\mathrm{PrOH})\end{array}$ & 72.52 & 0.1360 & 7.54 \\
\hline \multicolumn{5}{|c|}{ Calcined } \\
\hline 1. & $\mathrm{BaSO}_{4}-\mathrm{EG}$ & 13.52 & 0.00513 & 1.517 \\
\hline 2. & $\mathrm{BaSO}_{4}-\mathrm{H}_{2} \mathrm{O}$ & 13.70 & 0.00604 & 1.764 \\
\hline 3. & $\begin{array}{l}\mathrm{BaSO}_{4}-800 \mathrm{Sp} \\
(\mathrm{PrOH})\end{array}$ & 18.13 & 0.03757 & 8.286 \\
\hline
\end{tabular}

preparation of mesoporous $\mathrm{BaSO}_{4}$ nano material.

In order to study the surface characteristics, the Infrared (IR) spectra of the mesoporous $\mathrm{BaSO}_{4}$ nano materials were examined. Figure 5 shows that IR spectra are substantially differed depending upon the solvents. The absorption peak appeared at about 3433 and $165 \mathrm{I} \mathrm{cm}^{-1}$ due to the stretch and deformation of adsorbed molecular water. The peaks having 1183.1123 and $1085 \mathrm{~cm}^{-1}$ are sulfate containing absorption bands. The ethylene glycol absorption band occurred around $2925 \mathrm{~cm}^{-1}$ and $1437 \mathrm{~cm}^{-1}$ which were consistent with the appearance of the methylene groups. In this case the intensity of etlylene glycol specific absorption peaks (A. B and C) were higher than propanol i.e., methanol $>$ ethanol $>n$ butyl alcohol > propanol which was due to the absorption of ethylene glycol still on the surface of mesoporous $\mathrm{BaSO}_{4}$ nano particles. It was suggested that the ethylene glycol was highly adsorbed onto the surface of the particles and then encapsulated in their pores. This proved that ethylene glycol integrates with the hy'drogen bonds on the surface of the

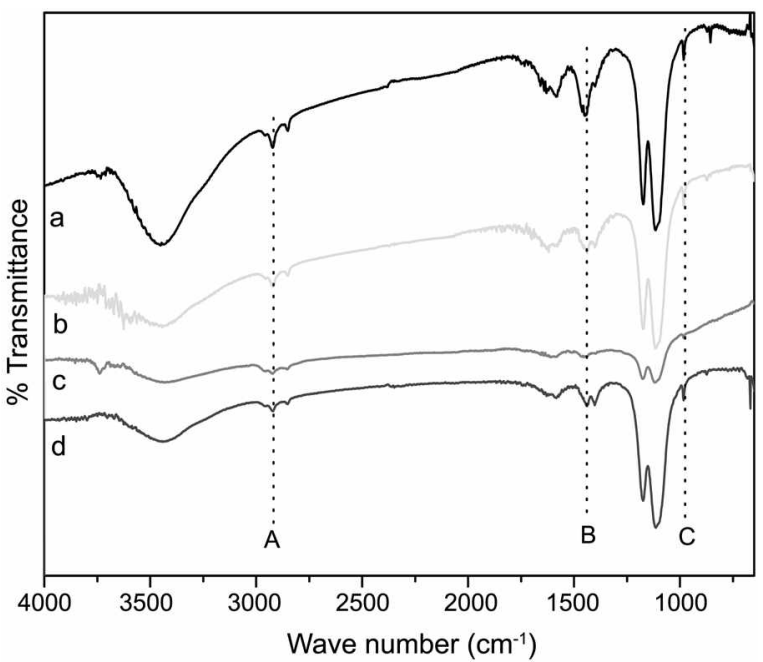

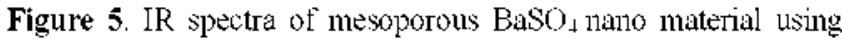
different solvents sprayed at $800^{\circ} \mathrm{C}$ a. $\mathrm{BaSO}_{+}-\mathrm{MeOH}$, b. BaSO$\mathrm{EtOH}$, c. $\mathrm{BaSO}_{4}-\mathrm{PrOH}$, d. $\mathrm{BaSO}_{4}-\mathrm{ButOH}$.

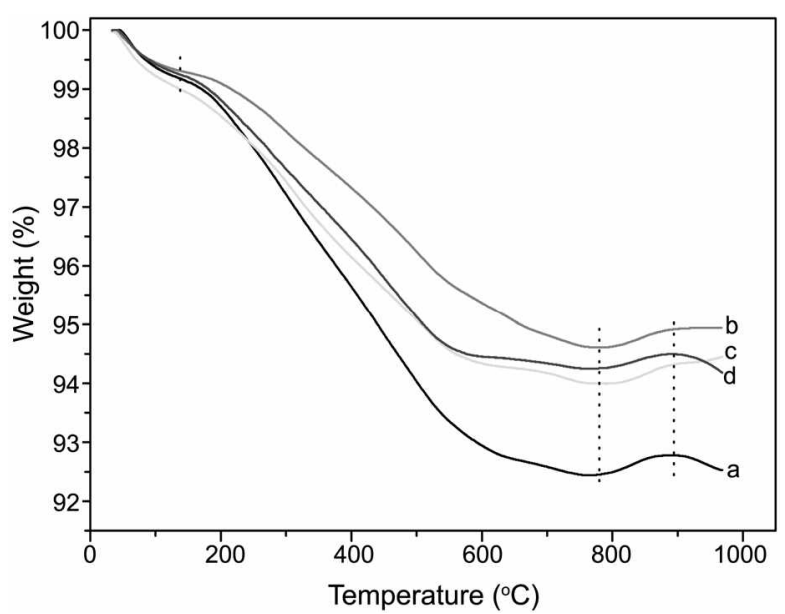

Figure 6. TGA pattems of mesoporous $\mathrm{BaSO}_{4}$-dried nano material obtained by using ethylene glycol as a reducing agent for the precipitation using different solvents sprayed at $800^{\circ} \mathrm{C}$. a. BaSOt $\mathrm{MeOH}$, b. BaSO $4-\mathrm{EtOH}$, c. $\mathrm{BaSO}_{4}-\mathrm{PrOH}_{7}$ d. $\mathrm{BaSO}_{4}-\mathrm{ButOH}$.

\section{$\mathrm{BaSO}_{4}$ nano material.}

In order to confirm the thermal behaviour of $\mathrm{BaSO}_{4}$ dried sample prepared by spray pyroly sis using different solvents. the coating amount of ethylene glycol in the sample were studied by thermo gravimetric analy sis (TGA) in the temperature range of $25-950^{\circ} \mathrm{C}$ as shown in Figure 6. When the temperature was changed from 130 to $770{ }^{\circ} \mathrm{C}$, the main weight loss was due to the loss of the adsorbed ethylene glycol (IR in Figure 5) on the surface of the $\mathrm{BaSO}_{4}$. Weight loss was obtained below $1 \%$ from room temperature to 190 ${ }^{\circ} \mathrm{C}$ due to desorption of phy sically adsorbed water. The result of low physically adsorbed water was consistent with the analy sis of active ratio and relative contact angle. The total weight losses obtained in mesoporous $\mathrm{BaSO}_{4}$ using different solvents from room temperature to $950^{\circ} \mathrm{C}$ shown in Table 3 . The curve in $\mathrm{BaSO}_{4}-\mathrm{PrOH}$ shows that the quantity of ethylene glycol adsorbed onto the surface of the $\mathrm{BaSO}_{4}$ was about $4.5456 \mathrm{wt} . \%$ at $130-770^{\circ} \mathrm{C}$ which is less compared to the other solvents. Because propanol has good inhibition effect on controlling the particle size and ethylene glycol will be distributed uniformly on the surface of $\mathrm{BaSO}_{4}$ at higher temperature. The temperatures at $790-895^{\circ} \mathrm{C}$ did not lead to the complete desorption of ethylene glycol due to its strong binding force which further indicates that a hydrogen bond was formed. However. in other solvents there is a

Table 3. Total weight loss of ethylene glycol obtained from themo gravimetric analysis of mesoporous $\mathrm{BaSO}_{4}$ nano material using different solvents prepared by spray pyrolysis

\begin{tabular}{|c|c|c|c|c|c|}
\hline \multirow{2}{*}{$\begin{array}{l}\text { Sl. } \\
\text { No. }\end{array}$} & \multirow[b]{2}{*}{ Samples } & \multicolumn{3}{|c|}{ Weight loss $(\%)$} & \multirow{2}{*}{$\begin{array}{c}\text { Total } \\
\text { teight } \\
\text { loss }(\%)\end{array}$} \\
\hline & & $\begin{array}{c}25-130 \\
{ }^{\circ} \mathrm{C}\end{array}$ & $\begin{array}{c}130-770 \\
{ }^{\circ} \mathrm{C}\end{array}$ & $\begin{array}{c}790-895 \\
\circ \mathrm{C}\end{array}$ & \\
\hline 1. & $\mathrm{BaSO}_{4}-\mathrm{MeOH}$ & 0.7731 & 6.787 & $0.3+41$ & 7.9042 \\
\hline 2. & $\mathrm{BaSO}-\mathrm{EtOH}$ & 0.6921 & 4.702 & 0.3540 & 5.7481 \\
\hline 3. & $\mathrm{BaSO}-\mathrm{PrOH}$ & 0.9854 & 4.5456 & - & 5.5310 \\
\hline 4. & $\mathrm{BaSO}-\mathrm{ButOH}$ & 0.7563 & 5,017 & 0.2463 & 60196 \\
\hline
\end{tabular}


weight loss at higher temperature because the hydrogen bond was formed between the ethylene glycol and solvents on the surface of the powder. leading to the aggregation of the particles.

\section{Conclusions}

We conclude that the mesoporous $\mathrm{BaSO}_{4}$ with high surface area nano material has been prepared by spray pyroly is at high temperature isolated with ethylene glycol using different additives. XRD analysis indicated that the product was highly pure in nature. Ethylene glycol controlled the mesoporosity, propanol maintained the morphology and particle size of the $\mathrm{BaSO}_{4}$ nano material. The future significance of this work is used for coating metal oxide by fluidized bed method for industrial applications such as low temperature sulphuric acid decomposition.

Acknowledgements. The authors wish to thank the financial support form MOST of Korea and KAERI. This work has been carried out under the Nuclear Hydrogen Development and Demonstration Project (NHDD).

\section{References}

1. Qi L.: Colfen, H.: Antonietti, M. Angew: Chem. 2000. 39(3). 604

2. Wong. D. C. Y.: Jaworski. Z.: Nienow A. W. Chem. Eng. Sci. 2001. 56.727 .

3. Qi. L: Cölfen. H: Antonietti. M.: Li. M.: Hopwood. J. D.: Ashley. A. J.: Mann, S. Chem. Euf. J. 2001. 7(16). 3526.
4. Judat. B.: Kind. M. J. Colloid hnterf. Sci. 2004. 269.341.

5. Robinson. K. L.: Weaver. I. V. M.: Armes. S. P.: Marti. E. D.: Meldrum. F. C. J. Hater Chent 2002. 12.890.

6. Summers. M.; Eastoe J:- Davis, S. Langmuir 2002. 18. 5023.

7. Yu. S. H.: Antonietti. M: Cölfen, H.: Hartmann. J. Kano Lett 2003. 3(3) 379 .

8. Li. M.: Colfen. H.: Mann1. S. J. Mater Chem. 2004. 1H. 2269.

9. Bala. H.: Fu. W.: Zhao. T.: Ding. X.: Tiang. Y.: Yu. K.: Wang. Z Colloid Surf. A: Phsicchem. Eng Aspects 2005. 252. 129.

10. Bala. H.; Fu, W: Guo, Y.: Zhao, J.: Ding. X.: Jiang, Y.: Ding, X: Yu. K.: Li. M.: Wang, Z. Colloid Swf. A. Phusicochem. Eng. Aspects 2006. 27t, 71 .

11. Li. F.: Yuant. G. Chent Contmum. 2005. 17. 2238

12. Li. F.: Yuan. G. J. Catal. 20166. 239. 282

13. Nagaraja. B. M.: Abimanyu. H.: Jung. K. D.: Yoo. K. S. J. Colloid Interf. Sci. 2007. 316,645.

14. Kodas. T. T. Adv Mater $1989,6.180$

15. Messing. G. L.: Zhang, S. C.: Jayanthi. G. V. J. Am. Ceram Soc. 1993. 76.2707 .

16. Gurav. A.: Kodas. T.: Pluym. T.: Xiong. Y. Aenosol Sci. Technol. 1993. 19.411

17. Che. S.: Yasuda. T.: Sadurai, O: Saiki, A.; Shinozaki, K: Mizutani, N. J. Ceram. Soc. Jpu 1997. 105. 269.

18. Kieda. N.: Messing. G. L. J. Hater: Sci. Letts. $1998,17,299$.

19. Arico. A. S.: Shukla. A. K.: el-Khatib. K. M.: Creti. P.: Antonucci. V. J. Appl. Electrochem. 1999. 29.671

20. Fievet. F.: Lagier. T. P.: Blin. B.: Beaudoin. B.: Figlaı. M. Solid State lonics $1989,3233.198$

21. Hill, R. J. Can. Mineral 1977.15, 522.

22. Sing. K. S. W: Everett, D. H: Haul, R. A. W: Moscow, L: Pierotti. R. A.: Rouquerol. J.: Siemieniewskia. T. Pure Appl. Chent 1985.57.603.

23. Jaycock. M. J.: Parfitt. G. D. Chentistry of Interfaces: Wiley: New York. 1981

24. Jia. Z.: Liu. Z:: He, F. J. Colloid hiterf. Sci. 2003, 266. 322. 